\title{
Bir Vakıf Üniversitesindeki Öğrencilerde Kronik Böbrek Yetmezliği Risk Faktörlerinin İcelenmesi*
}

\author{
Öğr. Gör. Aynur EKREN ÇAKICl', Prof. Dr. Nermin OLGUN² \\ 'Hasan Kalyoncu Üniversitesi Meslek Yüksekokulu Diyaliz Bölümü, GAZiANTEP \\ ${ }^{2}$ Hasan Kalyoncu Üniversitesi Sağılık Bilimleri Fakültesi Hemşirelik Bölümü Iç Hastalıkları Hemşireliği Anabilim Dalı, GAZiANTEP
}

\section{Araştırma}

Sorumlu Yazar

Aynur EKREN ÇAKICI

E-posta:Aynur.ekren@hku.edu.tr

ORCID:0000-0001-7502-0266

Nermin OLGUN

ORCID: 0000-0002-8704-4588

Geliş Tarihi: 06.05.2021

Kabul Tarihi: 09.06.2021

*Tez den üretilmiştir.

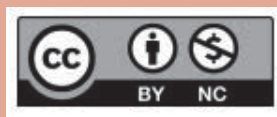

Özet

Amaç: Bu araştırma, bir vakıf üniversitesindeki öğrencilerde kronik böbrek yetmezliği risk faktörlerinin incelenmesi amacı ile tanımlayıcı olarak yapıldı.

Gereç ve Yöntemler: Araştırmanın evrenini Gaziantep ilinde bulunan bir vakıf üniversitesinde 2019-2020 güz döneminde öğrenim gören 6127 öğrenci, örneklemini ise çalısmaya gönüllü olarak katılan 1142 katılımcı oluşturdu. Veri toplama aracı olarak Sosyo-Demografik Özellikler formu ve Fin Diyabet Risk Skoru Ölçeği kullanıldı. Verilerin değerlendirilmesinde tanımlayıcı istatistiksel yöntemleri olarak sayı, yüzde, ortalama, standart sapma ile bağımsız gruplar arasındaki verilerin karşılaştııılmasında ise t-testi ve One Way ANOVA testi kullanıldı. Gruplu değişkenler arasındaki ilişki ki-kare analizi ile test edildi.

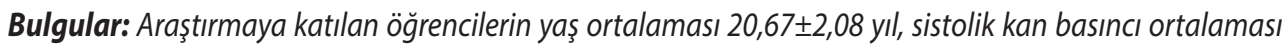
$112,00 \pm 12,20 \mathrm{mmHg}$, diyastolik kan basıncı ortalaması $71,80 \pm 9,32 \mathrm{mmHg}$, bel çevresi ortalaması 75,89 $\pm 11,08$ $\mathrm{cm}$ ve kilo ortalaması $64,20 \pm 13,50 \mathrm{~kg}$ olarak belirlendi. Araştırmaya katılan öğrencilerin ailede kronik hastalık varlığına göre Fin Diyabet Risk Skoru Ölçeği puan ortalamalarına bakıldığında; ailesinde kronik hastalık olan-

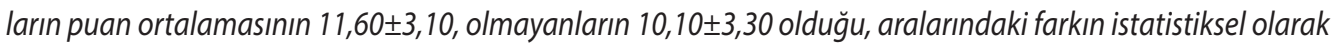
anlamlı olduğu belirlendi ( $p \leq 0,001)$. Bekarların evli olanlara göre puan ortalamalarının daha yüksek olduğu, aralarındaki farkın istatistiksel olarak anlamlı olduğu belirlendi $(p<0,05)$.

Sonuç: Araştırmanın sonucunda bel çevresi ve kilo arttıkça kronik böbrek yetmezliğinin risk faktörleri arasında yer alan diyabet gelişiminin arttığı belirlendi. Ailede kronik hastalık varlığının diyabet gelişiminde etkili olabileceği belirlendi. Ailesinde kronik hastalık olan gençlerin yaşam tarzını kronik böbrek yetmezliği risk faktörleri açısından dikkate alarak düzenlemesi önerilmektedir.

Anahtar kelimeler: Kronik Böbrek Yetmezliği; Findrisk; Diyabet; Hipertansiyon; Öğrenci

\section{Abstract}

Investigation of Risk Factors for Chronic Renal Failure Among Students at A Foundation University

Aim: This study was conducted as a descriptive study to analyze the risk factors of chronic renal failure students studying at a foundation university

Material and Methods: The population of the study consists of 6127 students, studying at a foundation university in Gaziantep during fall semester of 2019-2020 academic year. The sample of the study consisted of 1142 students who participated in the study voluntarily. Socio-demographic information form and Finnish Diabetes Risk Score were used as data collection tools. In the assessment of data, number, percentage, average and standard deviation were used as descriptive statistical methods. $t$-test and ANOVA were used in the comparison of data between independent groups.

Results: The association between paired variables was tested with Chi-square analysis. Average age of 
the students who participated in the study was found as $20.67 \pm 2.08$ year, average systolic blood pressure was found as $112.00 \pm 12.20 \mathrm{mmHg}$, average diastolic blood pressure was found as $71.80 \pm 9.320 \mathrm{mmHg}$ average waist circumference was found as $75.89 \pm 11.08 \mathrm{~cm}$ and average weight of the students was found as $64.20 \pm 13.50 \mathrm{~kg}$. When the average Finnish Diabetes Risk Score of the students were analysed in terms of the presence of chronic disease in the family, it was found that the average scores of

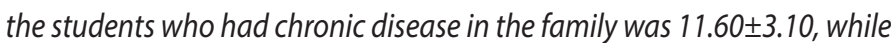
the average scores of the students who did not have chronic disease in the family was $10.10 \pm 3.30$ and the difference between was found to be statistically significant $(p=0,000)$. It was found that single participants had higher score averages than married participants and that the difference between was statistically significant $(p<0.05)$.

Conclusion: As a result of the study, it was found that as waist circumference and weight increased, the development of diabetes disease, which is among risk factors of chronic renal failure, also increased. It was found that the presence of chronic disease in the family could be effective in the development of diabetes. The exist of chronic diseases with genetic transition characteristics such as diabetes and hypertension is an important risk factor in the comprise of chronic renal failure. It is recommended that young people with chronic diseases in their family regulate their lifestyle by taking into account the risk factors of chronic renal failure.

Keywords: Chronic Renal Failure; Findrisk; Diabetes; Hypertension; Student.

\section{Giriş}

Kronik hastalıklar birden fazla risk faktörünün neden olduğu, 3 ay ve daha uzun süren bazen hayat boyu devam eden hastalıklar olarak tanımlanabilir (Akdemir ve Ünsar, 2020). Kronik hastalıklar, toplum sağlığını olumsuz etkileyen ölümlere neden olan önemli sağlık sorunlarının başında gelmektedir (Durna, 2012). Kronik hastalıklar kişilerin sosyal yaşamını, öğrencilerin okul hayatını, çalışanların iş hayatını ve aile içindeki rollerinde ve sorumluluklarında yaşam kalitelerini etkileyen bir sağlık sorunudur (Durna, 2012; Atasoy, Çolak, Akdeniz, Tanrısev ve Özyurt, 2013).

Kronik Böbrek Yetmezliği (KBY), böbrek fonksiyonlarının ilerleyici ve geri dönüşsüz (irreversible) olarak işlevini kaybetmesi ile tanımlanan kronik bir hastalıktır (Birol ve Çınar, 2020; Kaçar, 2012; Metin ve Kızıltan, 2013; Tanrıverdi, Karadağ ve Hatipoğlu, 2010). KBY son yıllarda prevelansı artan ve yaş ilerledikçe görülme sıklığı artan bir hastalık iken gençlerde ve çocuklarda da görülebilen hastalıklar arasında yer almaya başlamıştır (Metin ve KızIltan, 2013; Akan vd., 2010). KBY risk faktörlerinin tanılanması ve uygun önlemlerin alınması ile ilerlemesi yavaşlatılabilir bir hastalıktır. KBY bakımı zor, tedavisi uzun, komplikasyonlar açısından dikkat edilmesi gereken, iyi bir tedavi olmadığında tüm organları etkileyebilen zor ve masraflı bir hastalıktır (Metin ve Kızıltan, 2013; Tanrıverdi vd., 2010; Taş, Cengiz, Erdem, Karataş ve Coşkun, 2011).

Registry 2018 yılı raporuna göre Türkiye'de renal replasman tedavisi intiyacı olan Son Dönem Böbrek Hastalığı (SDBH) nokta prevelansı mil- yon nüfus başına 988,4 olarak saptanmıştır (Süleymanlar, Ateş ve Seyahi, 2019). 2018 Registry raporuna göre yılsonu itibari ile aynı zamanda SDBH gelişen ve hemodiyaliz (HD) tedavisine başlayan hastaların \%35,80'i Diabetes Mellitus (DM), \%27,38'i Hipertansiyon (HT) nedeni ile Periton Diyaliz Tedavisine (PD) başlayan hastaların ise \%33,40 ile HT, \%20,89'u ise DM ilk iki sırada yer almaktadır (Süleymanlar, Ateş ve Seyahi, 2019).

Kronik Böbrek Yetmezliği etyolojisine bakıldığı zaman risk oluşturan ilk iki hastalık arasında DM ve HT yer almaktadır (Yıldırım, Taşkıran, Erbaş ve Akar, 2016). Hipertansiyon erişkin hastalığı olarak bilinse de son yıllarda gençlerde ve çocuklarda da görülme sıklığı artmaktadır (Akan vd., 2010). Sedanter yaşama geçip hareketliliğin azalması, beslenme alışkanIıklarının değişerek obeziteye doğru artışın olması, hazır gıda tüketiminin artması, tuz tüketimin artmasına bağlı olarak hipertansiyon görülme sıkığının artmasına neden olmaktadır (Akan vd., 2010). Hipertansiyonun kendisi bir kronik hastalık olmasının yanında hedef organ tutulumu ile birçok hastalığa zemin hazırlamakla birlikte bunlar arasında KBY de yer almaktadır (Şenuzun ve Özer, 2012). Erken tanı ile hastalığa yönelik tedbirlerin alınması sağlanarak yaşam şeklinde düzenlemeler yaparak, stresten uzak durarak ve tedaviye erken başlanması ile hastalığın ilerlemesinin önüne geçilebilir (Şenuzun ve Özer, 2012).

Sağlık Bakanlığının hazırlamış olduğu Türkiye Böbrek Hastalıkları Önleme ve Kontrol Programı (2018-2023) eylem planında yer verdiği bilgilerde hastalığın erken tanısı, etkin izlem ve tedavi yöntemleri ile hastalığın ilerlemesinin önlenmesi, yavaşlatılması ve renal replasman tedavilerinin geciktirilmesi planlanmaktadır (Irmak, Yardım, Temel ve Keklik, 2018). Aynı zaman da sağlıklı bir yaşam şeklini benimseyerek, spor yaparak, düzenli ve dengeli beslenerek, tuz tüketimini azaltıp su tüketimini artırarak, sigaradan ve alkolden uzak durarak böbrek hastalığının gelişim nedenleri arasında yer alan DM ve HT gibi risk faktörlerinin kontrollerinin sağlanmasına katkı sağlayabilir (Irmak vd., 2018). Bunun için toplumun bilinçlendirilmesi, hastalıklar hakkında ve korunma yöntemleri hakkında bilgilendirilmesi erken tanı ve tedavi için eğitilmesi gerekmektedir (Irmak vd., 2018).

Amaç: Bu araştırma, bir vakıf üniversitesindeki öğrencilerde en yoğun KBY risk faktörleri arasında yer alan HT ve DM'a ait risk durumunun incelenmesi amacı ile yapılmıştır. Bu bağlamda aşağıdaki araştırma soruları incelenmiştir.

- Genç erişkinlerde KBY gelişmesi açısından risk oluşturan DM görülme riski nedir?

- Genç erişkinlerde Kronik Böbrek Yetmezliğinin gelişmesi açısından risk oluşturan Hipertansiyonun görülme sıklığı nedir?

Yöntem

Araştırmanın Türü: Bu çalışma tanımlayıcı tipte yapılmıştır.

Araştırmanın Yapıldığı Yer: Gaziantep ilinde bulunan bir vakıf üniversitesinde, 30 Eylül-15 Kasım 2019 tarihleri arasında yürütüldü.

Araştırmanın Evreni ve Örneklemi: Araştırmanın evrenini Gaziantep ilinde bulunan bir vakıf üniversitesinde 2019-2020 güz döneminde öğrenim gören lisans (5562) ve ön lisans (565) olmak üzere 6127 
öğrenci oluşturdu. Herhangi bir örnekleme yöntemine gidilmeyip evrenin tamamına ulaşması planlandı. Çalışmaya katıımayı kabul eden 1148 öğrenci araştırmanın örneklemini oluşturdu. Formların eksik doldurulması nedeniyle 6 öğrenci çalışmaya dahil edilmedi. Çalışma 1142 öğrenci ile tamamlandı.

Veri Toplama Araçları: Araştırmanın verileri Sosyo Demografik Özellikler Formu ve Fin Diyabet Risk Skoru Ölçeği (FiNDRiSK) kullanılarak toplandı.

Sosyo Demografik Özellikler Formu: Araştırmacı tarafından hazırlanan form; bireylerin ve ailesinin sosyo-demografik özelliklerine ilişkin yaş, cinsiyet, sigara ve alkol tüketme durumunu belirlemeye yönelik toplam 14 sorudan oluşmaktadır.

Fin Diyabet Risk Skoru Ölçeği (FiNDRiSK): Finlandiya'da 2003 yılında kohort çalışması sonucu geliştirilen toplum tabanlı ve erişkinlerde diyabet riskini araştırmak için geliştirilmiş, sekiz sorudan oluşan ve kişilerin diyabet olma riskinin gelecek on yıl içindeki durumlarını gösteren bir ölçektir. Ölçeğin puan aralığı 0-26 arasındadır. Ölçekten alınacak 7 puan altı diyabet açısından düşük riski, 7-11 puan hafif riski, 12-14 puan orta riski, 15-20 puan yüksek riski ve 20 puan ve üzeri ise çok yüksek riski göstermektedir ( Kulak vd., 2019; Osman, 2020).

Araştırmanın Etik Yönü: Hasan Kalyoncu Üniversitesi Sağlık Bilimleri Enstitüsü Girişimsel Olmayan Araştırmalar Etik Kurulu'ndan etik kurul izni (Tarih: 14.06.2019 ve Etik Kurul No: 2019/42), Hasan Kalyoncu Üniversitesi Rektörlüğünden ise yazııı izin alındı. Öğrencilere çalışmaya katılmadan önce çalışmanın amacı, gönüllülük esasına dayandığı, istedikleri zaman çalışmadan çıkabilecekleri, çalışmanın amacı ve toplanan verilerin gizliliği hakkında bilgi verilmiş olup, öğrencilerden sözlü onam alındı.

Verilerin Toplanması: Araştırma verileri, etik kurul ve kurum izni alındıktan sonra, sözlü onamları alınan öğrencilerden Sosyo Demografik Özellikler Formu ve FINDRiSK formlarının doldurulması istendi. Ayrıca her öğrenci için tansiyon ve bel çevresi ölçümü yapıldı. Çalışmaya katılmak isteyen öğrencilerden en az 5 dakika dinlenmeleri istendikten sonra sınıf ortamında toplandı. Kan Basıncı ölçümleri öğrenciler oturur pozisyonda iken, bel çevresi ölçümleri ise öğrenciler ayakta iken yapıldı. Veri toplama işlemi her bir katılımcı için ortalama 4-5 dakika sürdü.

Verilerin Değerlendirilmesi: Araştırmada elde edilen veriler SPSS (Statistical Package for Social Sciences) for Windows 21 programı ile analiz edildi. Verilerin değerlendirilmesinde sayı, yüzde, ortalama, standart sapma, t-testi ve One Way ANOVA testi kullanıldı. Gruplu değişkenler arasındaki ilişki ki-kare analizi ile test edildi. İstatistiksel kararlarda $\mathrm{p} \leq 0,05$ seviyesi anlamlı farklılık olarak kabul edildi.

Araştırmanın Sınırlılıkları: Araştırma, hukuk fakültesinde devam zorunluluğu olmamasından dolayı öğrencilere ulaşılamaması, araştırmanın yapıldığı günlerde bazı öğrencilerin devamsızlık haklarını kullanmaları ve çalışmaya katılmak istemeyen öğrenciler ile sınırıdır.

\section{Bulgular}

Genç erişkin olan üniversite öğrencilerinin KBY açısından risk faktörlerinin araştırılması amacıyla yapılan araştırmada, öğrencilerin \%69,8'inin kadın, \%97,7'sinin bekar, \%71,6'sının sigara içmediği, \%83,2'sinin alkol kullanmadığı saptandı. Araştırmaya katılan öğrencilerin $\% 55,1^{\prime}$ ' inin ailesinde kronik bir hastalık olduğu, \%84,7'sinin tanısı konulmuş bir hastalığı olmadığı, \%90,3'nün düzenli ilaç kullanmadığı belirlendi (Tablo 1).

Araştırmaya katılan öğrencilerin yaş ortalaması $20,60 \pm 2,00$ yıl, sistolik kan basıncı ortalaması 112,00 $\pm 12,20 \mathrm{mmHg}$, diyastolik kan basın-

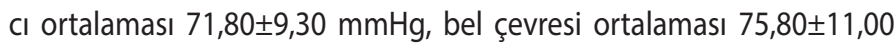
cm ve kilo ortalaması $64,20 \pm 13,50 \mathrm{~kg}$ olarak bulundu (Tablo 1).

Fin Diyabet Risk Skoru Ölçeğine göre Tip-2 Diyabet risk derecesi değerlendirildiğinde, katılanların \%4,1'inin düşük, \%45,2'sinin hafif, \%39,3'nün orta, \%10,7'sinin yüksek risk grubunda olduğu ve FiNDRiSK

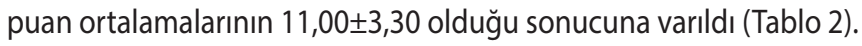

Kadınların FiNDRiSK puan ortalamasının $(11,00 \pm 3,20)$, erkeklerden $(10,90 \pm 3,40)$ daha yüksek olduğu, fakat aralarındaki istatistiksel olarak farkın anlamlı olmadığı ( $p>0,05)$; bekarların $(12,80 \pm 3,60)$, evli olanlara $(10,90 \pm 3,30)$ göre FiNDRiSK puan ortalamalarının daha yüksek olduğu, aralarındaki farkın istatistiksel olarak anlamlı olduğu belirlendi $(p<0,05)$. Sigara içenlerin $(11,00 \pm 3,30)$, içmeyenlere $(10,90 \pm 3,30)$ göre FiNDRiSK puan ortalamasının daha yüksek olmasına rağmen aralarındaki farkın istatistiksel olarak anlamlı olmadığı görüldü $(p>0,05)$. Ailesinde kronik hastalık olanların FiNDRiSK puan ortalamasının $(11,60 \pm 3,10)$, olmayanlardan $(10,10 \pm 3,30)$ yüksek olduğu, aralarındaki farkın istatistiksel olarak anlamlı olduğu saptandı $(p<0,05)$. Birinci derece yakınlarında DM olanların FiNDRISK puan ortalamalarının $(13,40 \pm 2,40)$, ikinci derece yakınlarında DM olanlardan $(11,60 \pm 2,50)$ ve ailesinde DM olmayanlardan $(8,40 \pm 2,40)$ yüksek olduğu, aralarındaki farkın istatistiksel olarak anlamlı olduğu belirlendi $(p<0,05)$. Bel çevresi, 'erkek 94-102 cm arası/kadın 80-88 cm' arası olanların $(19,70 \pm 3,10)$ en yüksek, 'erkek $94 \mathrm{~cm} /$ kadın $80 \mathrm{~cm}$ ' altında olan-

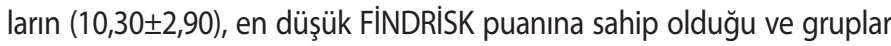
arasındaki farkın anlamlı olduğu sonucuna varıldı $(p<0,05)$ (Tablo 3$)$.

Öğrencilerin sistolik kan basıncına bakıldığında, \%60,9'u optimal, \%27,3'ü normal, \%10,1'i yüksek normal düzeyde; Diyastolik kan basıncına bakıldığında; \%63,4'ü optimal, \%29,5'i normal düzeyde olduğu bulundu. Grade 3 HT ve İzole Sistolik HT bulgularına rastlanılmadığı için tabloda gösterilmedi (Tablo 4).

Öğrencilerin FiNDRISK skorunun dağılımına bakıldığında, tamamının 45 yaşından küçük; \%76,9'unun beden kitle indeksinin 25 kg/ $\mathrm{m}^{2}$ 'den az; \%83,1'nin bel çevresinin erkeklerde $94 \mathrm{~cm}$ altında ve kadınlarda $80 \mathrm{~cm}$ altında olduğu saptandı. Katılanların \%94'ünün günde en az 30 dakika egzersiz yaptığı; \%53,8'inin her gün meyve-sebze tüketmediği; \%98,5'inde hipertansiyon olmadığı ya da antihipertansif ilaç kullanmadığı, \%89'unda yüksek veya sınırda kan şekeri ölçümü olmadığı; \%40,5'inin aile bireylerinde DM olmadığı belirlendi (Tablo 5).

\section{Tartışma}

Kronik Böbrek Yetmezliği dünyada ve ülkemizde yaygın bir şekilde görülen, kişiyi maddi manevi şekilde etkileyen önemli bir halk sağlı- 
ğı sorunu olarak kişinin yaşam şeklini değiştirmesi gereken kronik bir hastalıktır. Genelde orta yaş ve üzerinde görülürken günümüzde genç erişkinlerde hatta çocukluk çağında da görülmeye başlaması bu yaş grubu için dikkat edilmesi gereken unsurları göz önüne getirmektedir (Şahin, 2018). KBY açısından risk oluşturan en önemli etkenlerden ilk ikisi DM ve HT'dur (Süleymanlar vd., 2019).

Çalışmamızda KBY açısından DM risk faktörlerini incelediğimizde, öğrencilerin \%45,2'sinin yaklaşık yarısının 10 yıl içinde diyabet gelişme riskinin hafif risk grubunda, \%39,2'sinin önemli bir kısmının (\%39,2'si) orta derecede risk grubunda yer aldığı belirlendi. Doğan vd. üniversite öğrencileri ve çalışanlarında yaptığı çalışmada bu çalışmadan farklı olarak öğrencilerin \%32,5 düşük risk, \%3,5 orta risk \%1,5 yüksek ve çok yüksek risk grubunda olduğu belirlenmiştir (Doğan, Yörük, Öner, Yavuz ve Oğuz, 2017). Gezer (2017) yapmış olduğu çalışmada bu çalışmadan farklı olarak öğrencilerin $\% 67,1^{\prime}$ inin düşük risk grubunda, $\% 28,5^{\prime}$ inin hafif risk grubunda olduğunu belirlemiştir. Öğrencileri 10 yıllık DM gelişme riski açısından inceleyen Topbaş (2019) katılanların \%70'inin DM gelişme riskinin düşük, \%27,1'inin hafif risk grubunda olduğunu belirtmiştir. Demirağ vd. yaptıkları çalışmada katılanların $\% 83,4^{\prime}$ ünün düşük risk grubunda, \%13,6'sının ise hafif risk grubunda olduğunu belirlemişlerdir (Demirağ, Hintistan, Tunvay ve Cin, 2018). Bu çalışmada öğrencilerin KBY açısından risk oluşturan DM gelişme riskinin farklılık göstermesinin nedeni, DM varlığının, katılımcıların birinci derece aile yakınlarında \%16,7, ikinci derece aile yakınlarında $\% 52$ ve toplamda $\% 68,7$ oranında olduğu ve öğrencilerin çoğunluğunun en çok yaşadığı bölgenin beslenme alışkanlıklarının diğer bölgelerden farklı olan Güneydoğu Anadolu bölgesi olmasından kaynaklandığı düşünülmektedir.

Bu çalışmada tip 2 diyabet riski açısından kadınların puan ortalamaları erkeklerden fazla iken aralarındaki farkın anlamlı olmadığı belirlendi. Demirağ vd. çalışmalarında cinsiyet ve diyabet riski arasında istatiksel olarak anlamlı bir fark bulmamışlardır (Demirağ vd. 2018). Gezer (2017) çalışmasında kadın öğrencilerin puan ortalamasının erkek öğrencilerden anlamlı bir şekilde daha yüksek olduğunu belirle-

Tablo 2: Katılımcıların FiNDRiSK Ölçeği Puanlarına Göre Tip-2 Diyabet Risk Derecesi ve On Yıllık Risk Durumları ( $n=1142$ )

$\begin{array}{lllll} & \text { Sayı } & \% & \begin{array}{l}\text { Risk } \\ \text { Derecesi }\end{array} & \begin{array}{l}\text { 10 Yıllık Risk } \\ \text { Derecesi }\end{array} \\ <7 & 47 & 4,1 & \begin{array}{l}\text { Düşük } \\ (\% 1)(1 / 100)\end{array} \\ 7-11 & 516 & 45,2 & \text { Hafif } & (\% 4)(1 / 25) \\ 12-14 & 449 & 39,3 & \text { Orta } & (\% 16)(1 / 6) \\ 15-20 & 122 & 10,7 & \text { Yüksek } & (\% 33)(1 / 3) \\ >20 & 8 & 0,7 & \text { Çok yüksek } & (\% 50)(1 / 2)\end{array}$

$\begin{array}{lll}\text { FiNDRiSK } & \text { Min-Max } & \text { Ort } \pm \text { SS } \\ \text { Toplam Puanı } & 2-21 & 11,0 \pm 3,3 \\ \text { Ort } \pm S S=\text { ortalama } \pm \text { standart sapma } & \end{array}$

miştir. Topbaş'ın (2019) yaptığı çalışmada cinsiyetin Tip 2 diyabet riski açısından etkili olmadığını tespit etmiştir.

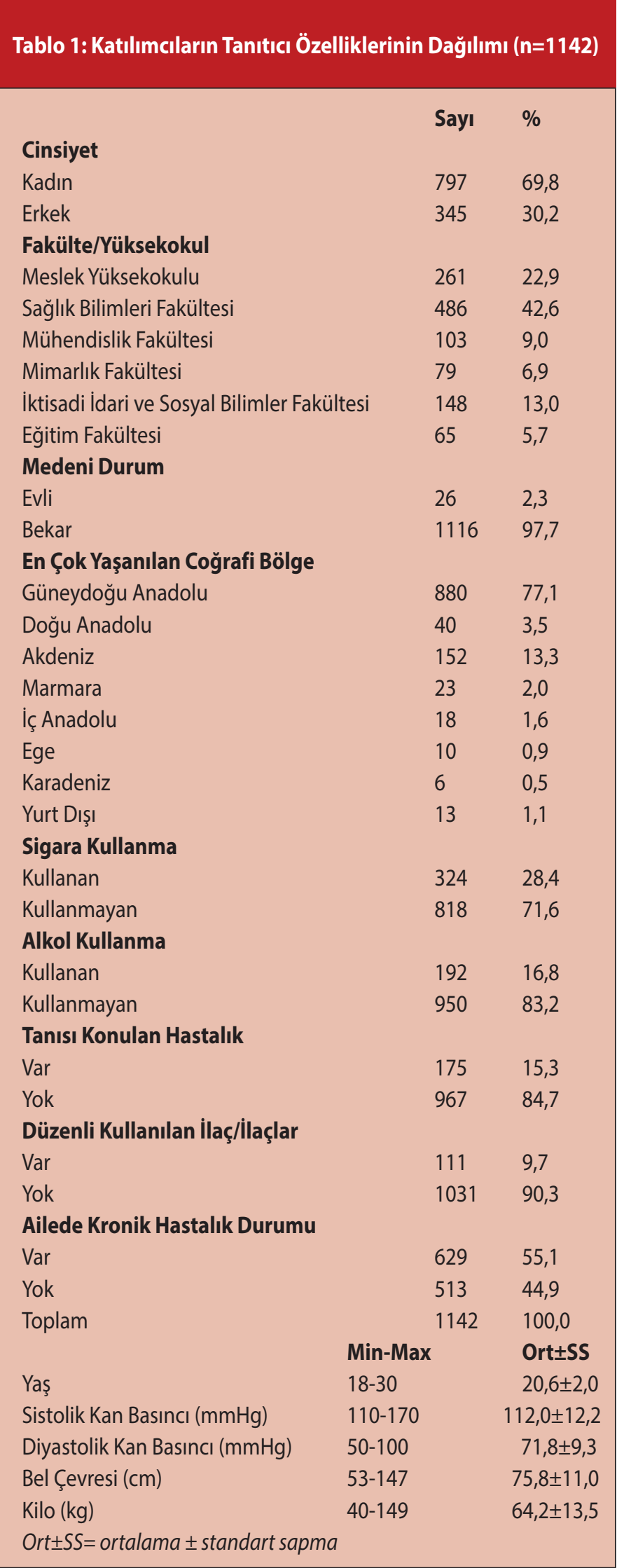


$\mathrm{Bu}$ çalışmada öğrencilerin medeni durumuna göre FiNDRiSK puan ortalamaları incelendiğinde bekarların evli olanlara göre puan ortalamalarının daha yüksek olduğu, aralarındaki farkın anlamlı olduğu belirlendi. Öğrenci grupları ile yapılan çalışmalarda FiNDRiSK puan ortalamaları evli olma durumlarına göre değerlendirilme literatürde rastlanmadı. Bu yönü ile çalışma literatüre yenilik ve katkı sağlayacaktır. Bu çalışmada bekarların puan ortalamalarının yüksek çıkmasının nedeni üniversite öğrencilerinde yaşam tarzı, beslenme şekli (hazır gıdalara yönelme, sebze ve meyve tüketiminin az olması vb.) ve hareketsiz yaşamdan kaynaklı olduğu düşünülmektedir.

Çalışmada araştırmaya katılan öğrencilerin ailede kronik hastalık varlığına göre FiNDRiSK puan ortalamalarına bakıldığında; ailesinde kronik hastalık olanların puan ortalamasının $(11,6 \pm 3,1)$, olmayanlardan $(10,1 \pm 3,3)$ daha yüksek olduğu ve aralarındaki farkın istatistiksel olarak anlamlı olduğu belirlendi. Avşar vd. çalışmasında her dört öğrenciden birinin ailesinde kronik hastalık olduğunu belirtmiş ve öğrencilerinde risk altında olduğunu belirtmişlerdir (Avşar, Kazan ve Pınar, 2013). Birinci derece yakınlarında DM olanların FiNDRISK puan ortalamasının $(13,4 \pm 2,4)$, ikinci derece yakınlarında DM olanların puan ortalamasından $(11,6 \pm 2,5)$ daha yüksek olduğu belirlenmiş olup, en düşük puan ortalamasının $(8,4 \pm 2,4)$ ise ailesinde DM olmayanların olduğu belirlenmiştir. Ailede DM olma durumu ile FiNDRISK puan ortalamaları arasındaki farkın istatistiksel olarak anlamlı olduğu belirlenmiştir. Demirağ vd. yaptığı çalışmada da benzer şekilde birinci derece ve ikinci derece yakınlarında DM olanların olmayanlara göre daha riskli olduğu istatiksel olarak anlamlı bulunmuştur (Demirağ vd., 2018). Bunun nedeninin KBY gelişimini etkileyen en önemli kronik hastalıklardan biri olan DM'un aile yakınlarında olması genetik olarak bireyleri etkilediği ve nesilden nesile geçen bir hastalık olmasının olduğu söylenebilir.

Çalışmada öğrencilerin sigara içme ve alkol alma durumuna göre FINDRISK puan ortalamaları incelendiğinde anlamlı bir fark bulunmadı. Benzer olarak Demirağ vd. yaptığı çalışmada da sigara içenlerin FiNDRISK puan ortalamalarında anlamlı bir fark bulunmamıştır (Demirağ vd., 2018). Topbaş'ın (2015) çaıışmasında da bu çalışmadan farklı olarak sigara içen, alkol kullanan bireylerin FiNDRiSK puan ortalamaları arasındaki farkın anlamlı olduğu saptanmıştır.

Çalışmada bel çevresi ölçüsüne göre FiNDRiSK puan ortalamaları arasındaki farkın anlamlı olduğu bel çevresi ölçümü arttıkça FiNDRiSK puanlarının arttığı ve diyabet olma riskinin arttığı belirlendi. Bakırezen (2016) çalışmasında bu ça-

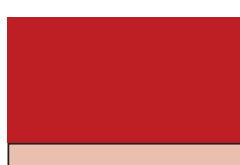

Cinsiyet

Kadın

Erkek

\section{Fakülte/Yüksekokul}

Meslek Yüksekokulu (MYO)

Sağlık Bilimleri Fakültesi (SBF)

Mühendislik Fakültesi

Mimarlık Fakültesi

İktisadi İdari ve Sosyal Bilimler

Fakültesi (iisBF)

Eğitim Fakültesi

Medeni Durum*

Evli

Bekar

En Çok Yaşanılan Coğrafi Bölge*

Doğu/Güneydoğu Anadolu

Diğer Bölgeler

Sigara İçme Durumu*

Var

Yok

\section{Alkol Alma Durumu*}

Var

Yok

\section{Tanısı Konulmuş Bir Hastalık*} Var

Yok

Düzenli Kullanılan Ilaç/ilaçlar* Var

Yok

Ailede Kronik Hastalık Durumu* Var

Yok

Ailede Diyabet Olma Durumu**

Evet, Birinci Derece Akrabada

Evet, İkinci Derece Akrabada

Hayır

\section{Bel Çevresi Ölçüsü**}

- Erkek: 94 cm altında / Kadın: $80 \mathrm{~cm}$ altında

- Erkek: $94-102 \mathrm{~cm}$ arası / Kadın: $80-88 \mathrm{~cm}$ arası

- Erkek: $102 \mathrm{~cm}$ üstü / Kadın: $88 \mathrm{~cm}$ üstü

* Bağımsız Gruplarda t Testi, ** FOne Way Anova Testi.

\section{Ort $\pm S S$}

797

345

$11,0 \pm 3,2$

$10,9 \pm 3,4$

$=0,138$

$p=0,890$

$10,8 \pm 3,3$

$486 \quad 11,1 \pm 3,1$

$103 \quad 11,1 \pm 3,5$

$79 \quad 10,6 \pm 3,6$

** $\mathrm{F}=0,789$

$p=0,558$

$148 \quad 10,7 \pm 3,3$

$65 \quad 11,3 \pm 3,2$

$26 \quad 10,9 \pm 3,3$

${ }^{*} \mathrm{t}=-2,908$

1116

$12,8 \pm 3,6$

$p=0,004$

880

$11,0 \pm 3,2$

${ }^{*} \mathrm{t}=-0,129$

262

$11,0 \pm 3,5$

$p=0,897$

818

$11,0 \pm 3,3$

${ }^{*} \mathrm{t}=0,371$

324

$10,9 \pm 3,3$

$p=0,711$

192

$10,8 \pm 3,3$

${ }^{*} t=0,853$

950

$11,0 \pm 3,3$

$p=0,394$

175

$10,9 \pm 3,7$

${ }^{*} \mathrm{t}=-0,311$

967

$11,0 \pm 3,2$

$p=0,756$

111

$11,1 \pm 3,9$

${ }^{*} \mathrm{t}=-0,371$

$11,0 \pm 3,2$

$p=0,711$

629

$11,6 \pm 3,1$

${ }^{*} t=-7,787$

$10,1 \pm 3,3$

$\mathrm{p}=0,000$

$13,4 \pm 2,4$

** $\mathrm{F}=458,1$

$11,6 \pm 2,5$

$\mathrm{p}=0,00$

$8,4 \pm 2,4$

949

$10,3 \pm 2,9$

127

$19,7 \pm 3,1$

**F $\mathrm{F}=147,7$ $\mathrm{p}=0,00$

\section{.}

\section{.}


Iışmaya benzer sonuçlar elde etmiş olup bel çevreleri arttıkça tip 2 Diyabet puanlarının anlamlı bir şekilde arttığını belirlemiştir. Demirağ vd. çalışmamıza benzer sonuçlar elde ettikleri çalışmalarında FiNDRiSK puan ortalamaları ile bel çevrelerini incelediğinde erkeklerde ve kadınlarda bel çevresi ölçümünü istatiksel olarak anlamlı bulmuşlardır (Demirağ vd., 2018). Gezer (2017) çalışmasında bel çevresi ölçümü ile Tip 2 diyabet arasındaki ilişkiyi düşük düzeyde saptamıştır. Bel çevresi genişliği arttıkça Tip 2 diyabet gelişme riski artmaktadır.

Bu çalışmada KBY açısından ilk sıralarda yer alan HT varlığını belirlemek için baktığımız tansiyon ölçümlerinde çalışmaya katılanların sistolik kan basıncının; \%60,9'unun optimal, \%27,3'ünün normal, \%10,1'inin yüksek normal, \%1,6'sının grade $1 \mathrm{HT}, \% 1$ inin grade 2 HT olduğu belirlendi. Diyastolik kan basıncının; $\% 63,4$ 'ünün optimal, \%29,5'inin normal, \%0,1'inin yüksek normal, \%6,5'inin grade 1 HT, \%0.5'inin grade $2 \mathrm{HT}$ olduğu belirlendi. Çalışmamız da sistolik kan basıncı ortalaması 112,0 $\pm 12,2 \mathrm{mmHg}$, diyastolik kan basıncı ortalaması 71,8 $\pm 9,32 \mathrm{mmHg}$ olarak belirlendi. Çelik vd. yaptıkları çalışmada bizim çalışmamızdan farklı olarak öğrencilerin \%5,4'ünde grade 1 hipertansiyon, \%0,5'inde grade 2 hipertansiyon varlığı tespit ederken \%57,1'inde normotansif, \%42,9'unda yüksek normal olarak bulmuşlardır (Çelik vd., 2012). Yabul'un (2011) çalışmasını KB ölçüm sonuçlarına göre değerlendirdiğimizde bu çalışmadan farklı olarak SKB ortalamasını $132 \pm 24,6 \mathrm{mmHg}$, DKB ise $83,6 \pm 13,6 \mathrm{mmHg}$ olarak saptamıştır. Akan vd. bu çalışmaya benzer şekilde 499 öğrenci ile yaptıkları çalışmada 430'u $(\% 86,2)$ normotansif, 56'sı $(\% 11,2)$ prehipertansif, 13'ü $(\% 2,6)$ hipertansif olarak saptamışlardır (Akan vd., 2010). TEKHARF çalışmalarının verilerinde yaş arttıkça KB değerlerinin arttığı saptanmıştır (Onat, 2017). Yabul'un çalışmasında bizim çalışmamızdan farklı olarak KB ölçümlerinin yüksek olmasının nedeninin, çalışma grubunun yaş ortalamasının 48,2 215,9 olmasından kaynaklandığı düşünülmektedir (Yabul. 2011).

Bu araştırmada FiNDRiSK değeri ile kilo arasında pozitif yönlü bir ilişki olduğu belirlendi. Bakırezen (2016) çalışmasında BKi ve kilo açısından diyabet riskini incelediğinde obez olan öğren- cilerde diyabet riskinin arttığını saptamıştır. Demirağ vd. BKi arttıkça diyabet riskinin artığını saptamışlar bu da bizim çalışmamız ile paralellik göstermektedir (Demirağ vd., 2018). Avşar vd. yapmış olduğu çaIışmalarında öğrencilerin \% 14,1'nin orta düzey şişman \%2,4'nün obez olduğunu belirtmişlerdir (Avşar, 2013). Obezite, Diyabet ve Hipertansi-

\section{Tablo 5: Katılımcıların FiNDRiSK Skorunun Dağı̆ımı ( $\mathrm{n=1142)}$}

\begin{tabular}{|c|c|c|}
\hline & Sayı & $\%$ \\
\hline \multicolumn{3}{|l|}{ Yaş } \\
\hline$<45$ & 1142 & 100 \\
\hline \multicolumn{3}{|l|}{ BKI } \\
\hline $25 \mathrm{~kg} / \mathrm{m}^{2}$ & 878 & 76,9 \\
\hline $25-30 \mathrm{~kg} / \mathrm{m}^{2}$ & 29 & 2,5 \\
\hline $30 \mathrm{~kg} / \mathrm{m}^{2}$ & 235 & 20,6 \\
\hline \multicolumn{3}{|l|}{ Bel Çevresi } \\
\hline Erkek: 94 cm altında / Kadın: $80 \mathrm{~cm}$ altında & 949 & 83,1 \\
\hline Erkek: $94-102 \mathrm{~cm}$ arası / Kadın: $80-88 \mathrm{~cm}$ arası & 127 & 11,1 \\
\hline Erkek: 102 cm üstü / Kadın: 88 cm üstü & 66 & 5,8 \\
\hline \multicolumn{3}{|l|}{ Günde En Az 30 Dakika Egzersiz Yapma } \\
\hline Evet & 1073 & 94,0 \\
\hline Hayır & 69 & 6,0 \\
\hline \multicolumn{3}{|l|}{ Sebze-Meyve Tüketim Sıklığı } \\
\hline Her Gün & 528 & 46,2 \\
\hline Her Gün Değil & 614 & 53,8 \\
\hline \multicolumn{3}{|c|}{ Hipertansiyon Varlığı / Antihipertansif İlaç Kullanımı } \\
\hline Evet & 17 & 1,5 \\
\hline Hayır & 1125 & 98,5 \\
\hline \multicolumn{3}{|l|}{ Yüksek veya Sınırda Kan Şekeri } \\
\hline Evet & 126 & 11,0 \\
\hline Hayır & 1016 & 89,0 \\
\hline \multicolumn{3}{|l|}{ Aile Bireylerinin Herhangi Birinde Diyabet Öyküsü } \\
\hline Birinci Derece & 423 & 37,0 \\
\hline İkinci Derece & 257 & 22,5 \\
\hline Yok & 462 & 40,5 \\
\hline
\end{tabular}

Tablo 4: Katılımcıların Kan Basıncının Sinıfandırılması ( $\mathrm{n=1142)}$

\begin{tabular}{|c|c|c|c|c|}
\hline & \multicolumn{2}{|c|}{ Sistolik Kan Basıncı } & \multicolumn{2}{|c|}{ Diyastolik Kan Basıncı } \\
\hline & Sayı & $\%$ & Sayı & $\%$ \\
\hline Optimal & 696 & 60,9 & 724 & 63,4 \\
\hline Normal & 312 & 27,3 & 337 & 29,5 \\
\hline Yüksek Normal & 115 & 10,1 & 1 & 0,1 \\
\hline Grade $1 \mathrm{HT}$ & 18 & 1,6 & 74 & 6,5 \\
\hline Grade 2 HT & 1 & 0,1 & 6 & 0,5 \\
\hline Toplam & 1142 & 100,0 & 1142 & 1142 \\
\hline
\end{tabular}

Avrupa Kardiyoloji Derneği/Avrupa Hipertansiyon Derneği Kılavuzu (2018) sınıflandırılmasına göre düzenlenmiştir. 
yon gibi kronik hastalıklarının gelişimi açısından risk oluşturmaktadır. Öğrencilerin hazır gıdalar ve kalorisi yüksek yiyecek ve içecekleri tüketmeleri hareketsiz yaşam gibi nedenlerle kilo almaları kaçınılmazdır. Obezitenin ilerleyen dönemlerde ciddi bir sağlık sorunu haline dönüşmeden gerekli önlemlerin alınması gerekmektedir.

\section{Sonuç ve Öneriler}

\section{Sonuçlar}

Genç yetişkin olan üniversite öğrencilerinde KBY risk faktörlerini araştırmak için yapılan bu çalışmada; araştırmaya katılan öğrencilerden DM gelişimi için cinsiyetlerinin, bir fark oluşturmadığı, sigara ve alkol kullanma durumlarının DM açısından risk olarak etkilemediği belirlendi. Bekar olanların evlilere oranla daha fazla DM açısından risk oluşturduğu, bel çevresi ve kilo artışının DM oluşumu açısından riskli olduğu, ailede kronik hastalığın ve DM hastalığının varlığı DM riskini artırdığı, dolaylı olarak KBY riskini artırdığı belirlendi. Öğrencilerden büyük çoğunluğunun kan basıncı ölçümü sonucu kan basıncı normal- optimal olarak belirlenirken geri kalan az sayıda öğrencinin ölçüm sonuçları yüksek normal- grade1- grade 2 olarak belirlendi. Yaş grubu olarak Hipertansiyon açısından risk oluşturan bir grup öğrencinin olduğu belirlendi.

\section{Öneriler}

- Meyve, sebze tüketiminin arttırılması,

- Diyabet açısından risk oluşturan öğrencilerin laboratuvar testlerinin yapılarak taranması ve DM önleme programına katılmaları,

- $\quad$ Ailesinde kronik hastalık bulunan öğrencilerin düzenli kontrollere gitmesi,

- Obezite açısından risk oluşturan öğrencilerin düzenli egzersiz ve spor yaparak bel çevresi ve kilo artışının önlenmesi,

- Kan Basıncı yüksek ölçülen öğrencilerin kontrollere gitmesi önerilebilir.

- Kronik Böbrek Yetmezliği açısından risk oluşturan Kan Basıncı yüksek ölçülen öğrenciler Aile Sağlığı Merkezlerine laboratuvar ortamında ileri tetkik ve tahlil (Albumin, Glomerüler Filtrasyon Hızı (GFH) gibi) için yönlendirilebilir.

\section{Çıkar Çatışması}

Yazarlar arasında, bu makalede bildirilen çalışmayı etkileyebilecek hiçbir mali çıkar veya kişisel çatışma bulunmamaktadır.

\section{Kaynaklar}

1. Akan, H., İzırak, G., Tanrı̈̈ver, Ö., Kaspar, E., Yıldız, A., Tilev, S. M., ... Vitrinel, A. (2010). Ergenlerde Prehipertansiyon ve Hipertansiyon Sıklığı. Türk Aile Hek Derg., 14(3), 115-123.

2. Akdemir, N. ve Ünsar, S. (2020). Kronik Hastalıklar ve Sorunları. N. Akdemir ve L. Birol (Ed.), İç Hastalıkları ve Hemşirelik Bakımı (s. 253-267). Ankara : Akademisyen Kitabevi.

3. Atasoy, I., Çolak, H., Akdeniz, Y., Tanrısev, M., Özyurt, B. (2013). Kronik Böbrek Yetmezliğinde Yaşam Kalitesi. Tepecik Eğit Hast Derg., 23(3), 133-141.

4. Avşar, P., Kazan, E. E., Pınar, G. (2013). Üniversite Öğrencilerinin Beslenme Alışkanlıkları ile Obezite ve Kronik Hastalıklara Illişkin Risk Faktörlerinin İncelenmesi. Yıldırım Beyazıt Üni- versitesi Hemşirelik Dergisi, 1(1), 38-46.

5. Bakırezen, M. M. (2016). Doğu Akdeniz Üniversitesi'nde Öğrenim Gören Öğrencilerin Sağııkı Yaşam Biçimi Davranışları ve Tip 2 Diyabet Riskinin Belirlenmesi. Yayımlanmamış yüksek lisans tezi, Doğu Akdeniz Üniversitesi Öğretim ve Araştırma Enstitüsü Beslenme ve Diyetetik ABD, Gazimağusa, Kuzey Kıbrıs.

6. Birol, L. Ve Çınar Pakyüz S. (2020). Böbrek Hastalıkları ve Hemşirelik Bakımı. N. Akdemir ve L. Birol (Ed.), İ̧ Hastalıkları ve Hemşirelik Bakımı (s. 699-785). Güncellenmiş 5. Baskı. Ankara : Akademisyen Kitabevi.

7. Çelik, M. M., Üstün, I., Yengil, E., Demir, H. İ., Gülek, F., Gökçe, C. (2012). Tıp Fakültesi Öğrencilerinde Prehipertansiyon Sıklığının Araştırılması. Mustafa Kemal Üniv.Tıp Derg., 3(10), 1-8.

8. Demirağ, H., Hintistan, S., Tuncay, B., Cin, A. (2018). Sağlık Hizmetleri Meslek Yüksekokulu Öğrencilerinin Diyabet Risklerinin Belirlenmesi. İnönü Üniversitesi Sağlık Hizmetleri Meslek Yüksekokulu Dergisi, 6(2), 25-35.

9. Doğan, B., Yörük, N., Öner, C., Yavuz, G., Oğuz, A. (2017). Üniversite Öğrenci ve Çalışanlarının Diyabet Riski ve Beslenme Alışkanlıklarının Değerlendirilmesi. Türk Aile Hek Derg., 21(2), 50-55

10. Durna, Z. (2012). Kronik Hastalıklar ve Önemi. Z. Durna ( Ed.), Kronik Hastalıklar ve Bakım (s.1-8). İstanbul : Nobel Tıp Kitabevleri.

11. Gezer, C. (2017). Hemşirelik Bölümü Öğrencilerinde Bel/Boy Oranı ve Tip 2 Diyabet Riski Illişkisisnin Değerlendirilmesi. Journal oF Food and Health Science, 3(4), 141-149.

12. Irmak, H., Yardım, N., Temel, F., Keklik, K. (2018). Türkiye Böbrek Hastalıları Önleme ve Kontrol Programı Eylem Planı (2018-2023). T.C. Sağlık Bakanlığı Halk Sağlığı Genel Müdürlüğü. Ankara : Artı6 Medya Tanıtım Matbaa Ltd. Şti.

13. Kaçar, G. (2012). Kronik Böbrek Yetmezliği ve Bakım. Z. Durna (Ed.), Kronik Hastalıklar ve Bakım (s. 381-395). İstanbul : Nobel Tıp Kitabevleri.

14. Kulak E., Berber B., Temel H., Kutluay S. N., Yıldırım M., Dedeoğlu F. N., Çifçili S., Save D. (2019). Aile Hekimliğine Başvuran Bireylerde Tip 2 Diyabet Risk Düzeyinin Belirlenmesi. Türk Aile Hek Derg., 23(1), 20-30.

15. Metin, S. ve Kızıltan, G. (2013). Çocuklarda Kronik Böbrek Yetmezliği, Beslenme Ile Illgili Risk Faktörleri ve Tıbbi Beslenme Tedavisi. Türkiye Klinikleri J Nephrol, 8(2), 53-63.

16. Onat, A. (2017). Toplumumuzda Kan Basıncı ve Hipertansiyon. A Onat (Ed.), TEKHARF 2017 Tıp Dünyasının Kronik Hastalıklara Yaklaşımına Öncülük (s. 104-119). İstanbul; Logos Yayıncılık Tic. A.Ş,

17. Osman A O. (2020). Üniversite Öğrencilerinde Tip 2 Diyabet Riski, Davranışsal ve Ailesel Risk Faktörleri ile Tip 2 Diyabet Farkındalığı, ( Yüksek Lisans Tezi). Adnan Menderes Üniversitesi Sağlık Bilimleri Enstitüsü Hemşirelik ABD, Aydın.

18. Süleymanlar, G., Ateş, K., Seyahi, N. (2019). Türkiye'de Nefroloji, Diyaliz ve Transplantasyon. Ankara : Türk Nefroloji Derneği Yayınları. T.C. Sağlık Bakanlığı ve Türk Nefroloji Derneği Ortak Raporu.

19. Şahin, A. (2018). Kronik Böbrek Yetmezliği Tanısı Alan Diyabetik veya Hipertansif Hastalara Hemşire Tarafından Verilen Eğitimin Bazı Parametrelere ve Yaşam Kalitesine Etkisi. Yayımlanmamış yüksek lisans tezi, Hasan Kalyoncu Üniversitesi Sağlık Bilimleri Enstitütüsü Hemşirelik ABD, Gaziantep.

20. Şenuzun, F. ve Özer, S. (2012). Hipertansiyon ve Bakım. Z. Durna (Ed.), Kronik Hastalıklar ve Bakım (s. 95-110). İstanbul : Nobel Tıp Kitabevleri.

21. Taş, F. S., Cengiz, K., Erdem, E., Karataş, A., Coşkun, K. (2011). Akut ve Kronik Böbrek Yetmezliğinde Mortalite Nedenleri. Fırat Tıp Dergisi, 16(3), 120-124.

22. Tanrıverdi, M. H., Karadağ, A., Hatipoğlu, E. Ş. (2010). Kronik Böbrek Yetmezliği. Konuralp Tıp Dergisi, 2(2), 27-32.

23. Topbaş, E. (2015). Kronik Böbrek Hastalığının Önemi, Evreleri ve Evrelere Özgü Bakımı. Nefroloji Hemşireliği Dergisi, 10(1), 53-59.

24. Topbaş, E. (2019). Üniversite Öğrencilerinde Tip 2 DM Riski ve İlişkili Faktörler. ACU Sağlık Bil Derg., 10(4), 616-620.

25. Yabul, C. (2011). Konya Illinde Hipertansiyon Prevalansı ve Farkındalık. Yayımlanmamış uzmanlık tezi, Selçuk Üniversitesi Meram Tıp Fakültesi İç Hastalıkları ABD, Konya.

26. Yıldırım, M., Taşkıran, E., Erbaş, O., Akar, H., (2016). Kronik Böbrek Hastalığında Böbrek Naklinin Rolü ve Böbrek Naklinde Canlı Verici Adayının Değerlendirilmesi. FNG \& Bilim Tıp Transplantasyon Dergisi, 1(2), 67-71. 